\title{
Flower and Stamen Structures of Male-fertile and Male-sterile Chestnut (Castanea sativa Mill.) Cultivars
}

\author{
Cevriye Mert ${ }^{1}$ and Arif Soylu ${ }^{2}$ \\ Uludag University Faculty of Agriculture, Department of Horticulture, Gorukle Campus 16059, Bursa, \\ Turkey
}

AdDitional INDEX WORDS. male sterility, anther morphology

\begin{abstract}
Aвstract. The flower and stamen structures of four male-fertile ('Firdola', 'Karamehmet', 'Sariaslama', and 'Haciomer') and two male-sterile ('Osmanoglu' and 'Vakit Kestanesi') chestnut cultivars were evaluated using scanning electron and light microscopes. Anther dimensions and pollen production capabilities were also determined. Stamens of the male-fertile cultivars showed more distinct flowering habit than male-sterile cultivars, which failed to show visible flowering due to shorter stamens. Flower clusters on the catkins had six to seven flowers while the mean number of stamens per flower varied from 9.50 to 11.95 among the cultivars, except for 'Osmanoglu' with 2.60 stamens per flower. Some 'Osmanoglu' flowers had no stamens or abnormal stamens (e.g., lacking anthers) or abortive anthers. Stamens of the male-sterile cultivar Vakit Kestanesi had short filaments and small anthers with few or no pollen. The pollen number per anther was significantly lower in the male-sterile than in the male-fertile cultivars. Three different kinds of anther surface morphologies were determined among the cultivars. The surface structure of male-fertile cultivars consisted of polygonal epidermis cells. Male-sterile 'Osmanoglu' had long polygonal epidermis cells, which had a thread-like surface appearance. Male-sterile 'Vakit Kestanesi' had epidermis cells with hollow middles and swollen edges. In male-sterile cultivars the length of the anthers was significantly less than that of the male-fertile cultivars. The anther wall of the male-fertile cultivars consisted of three clearly different cell layers. However, the anther walls of the male-sterile cultivars were not complete in all cases, and the number of layers varied from one to three.
\end{abstract}

Chestnut is a monoecious fruit species. Catkins of chestnuts possess a spike-like structure, and two kinds of catkin exist. One is a pure staminate group, and the other one contains mixed catkins that have both staminate and pistillate flowers (Abbe, 1974). Catkin length, the number of flower clusters per catkin, and the number of flowers per cluster are variable among chestnut species, and the genotypes within the species (Bergamini, 1975; Breviglieri, 1951; Graves, 1962; Schad and Solignat, 1952; Soylu and Ayfer, 1981). European researchers have divided the chestnuts into four groups with respect to their staminate flower structure. These are astamine (having no stamen), brachistamine (having short stamens within the perigon), mesostamine (having stamens as long as the perigon), and longistamine (having stamens longer than the perigon) (Breviglieri, 1951; Morettini, 1949; Schad and Solignat, 1952; Solignat, 1958, 1973). In stamenless genotypes, flower primordia cannot develop the stamens or anthers as in $C$. sativa (Bencat, 1964; Breviglieri, 1951; Morettini, 1949; Schad and Solignat, 1952; Solignat, 1958; Soylu and Ayfer, 1981) and other chestnut species and hybrids (Graves, 1962; Jaynes, 1963; Omura and Akihama, 1980). Anther structure and pollen production varied significantly in the male-sterile genotypes (Soylu and Ayfer, 1981). Longistamine types are suitable pollenizers with respect to their pollen production and viability (Breviglieri, 1955; Schad and Solignat, 1952; Solignat, 1958; Soylu and Ayfer, 1981).

This paper is based on a portion of a thesis submitted by Cevriye Mert in partial fulfillment for the requirement for the $\mathrm{PhD}$ degree in horticulture. We thank Prof. Dr. Cengiz Baycu for valuable support during SEM studies. Thanks also to Dr. Ali Fuat Gokce and Dr. Zeynel Dalkilic for critical reading of the manuscript. We acknowledge the Scientific Research Center of Uludag University for financial support of this work.

1Corresponding author; e-mail cevmert@uludag.edu.tr

2Professor; e-mail arifsoylu@uludag.edu.tr
Male sterility in chestnuts might be the result of genetic composition, cytoplasmic causes, or chromosomal aberrations (Jaynes, 1963). Later studies conducted on hybrid seedlings suggested that sterility is conditioned by two (Soylu, 1992) or four genes (Bolvansky and Mendel, 1999).

Up to now there has been no research on the anatomical structure and surface morphology of the anthers of male-sterile and male-fertile genotypes in chestnuts. However, studies conducted on other plant species showed a close relationship between the anther structure and sterility (Chaudhury et al., 1992; Duvick, 1965; Kaul, 1988; Lillecrapp et al., 1999; Szabó et al., 1996; Weijer, 1952). In some plant species, sterile anther structure appeared as a series of mutant genotypes (Chaudhury, 1993). Various types of stamen abnormalities have been seen in sterile genotypes, such as normal filament with no anther (Kaul, 1988; Sanders et al., 1999; Weijer, 1952), small anthers (Duvick, 1965; Kaul, 1988), malformed anther, or short filaments (Estelle and Somerville cited in Chaudhury, 1993). Variations in the anther structure of the male-sterile chestnut genotypes were outlined (Soylu and Ayfer, 1981). However, reports on anatomical structures, surface morphology, and pollen production capability of the male-fertile and male-sterile genotypes have not been investigated yet.

The aim of this study was to determine staminate flower structure, dimensions of the anthers, anatomical structure and surface morphology of the anthers, and pollen production of the anthers in four male-fertile and two male-sterile chestnut cultivars selected for their high yield and high quality (Ayfer et al., 1986).

\section{Materials and Methods}

Plant material. Flowers of the male-fertile and male-sterile chestnut cultivars were used in the study. Male-fertile cultivars were 'Firdola'(PI62309), 'Karamehmet'(PI62304), 'Sariaslama' 
(PI 51111), and 'Haciomer' (PI 52214); male-sterile cultivars were 'Osmanoglu' (PI 51101) and 'Vakit Kestanesi' (PI 52112). All flower materials were obtained from the Atatürk Central Horticultural Research Institute at Yalova.

Collection AND FIXATION OF THE MATERIAL. Staminate catkins of the cultivars were collected at the time of full bloom and fixed in FAA solution (10 formalin : 5 glacial acetic acid : 50 ethanol : 35 water, by volume) (Sass, 1958).

ObSERVATION OF FLOWERING. Flowering of staminate catkins of the cultivars were observed at the time of full bloom to determine whether they showed visible flowering or not. The number of flowers per cluster and the number of stamens per flower were counted on the samples fixed in the FAA solution. Flowers were counted on 40 clusters and 50 staminate flowers using the stereomicroscope (SZ6045TR; Olympus Optical Co. Ltd., Tokyo). However, in 'Osmanoglu', the stamens were classified into three groups: without anthers (only filaments), with aborted anthers, and with normal anthers. Each group was counted separately.

Dimensions of THE AnTHERs. Samples of the anthers were placed on the microscope slide, a drop of glycerin was added, and they were covered with a slide cover. An ocular micrometer was used for measuring the dimensions of 30 anthers.

DETERMINATION OF THE POLLEN PRODUCTION PER ANTHER. For this purpose, the hemacytometric method was used. The prefixed male catkins in the FAA solution were rinsed for 10 min with a $50 \%, 70 \%, 95 \%$, and twice with a $100 \%$ ethanol solution, in series, respectively. One hundred unshed anthers were placed into the glass vial and left at room temperature to dry and release the pollen. Then, 2 mL of distilled water were added to each glass vial. A droplet of this solution was placed on a hemacytometric glass slide and covered with a thick microscope slide cover. Pollens were counted using a light microscope (BH-2; Olympus Optical Co.) in a sample of $1-\mathrm{mm}^{3}$ chamber volume and replicated four times for every vial.

Light MICROSCOPY (LM). Catkin samples prefixed in the FAA solution were washed three times in phosphate buffer $(\mathrm{pH}=7.2)$ for $20 \mathrm{~min}$. Then the samples were fixed in $1 \%$ osmium tetroxide for $2 \mathrm{~h}$, and washed four times in a phosphate buffer, and then
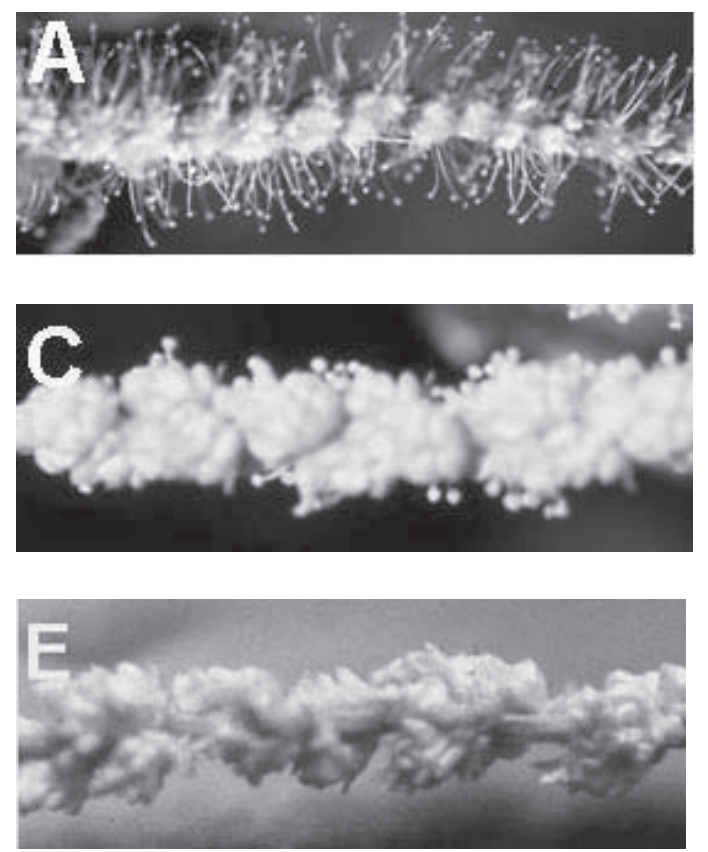

dehydrated for $10 \mathrm{~min}$ in a $50 \%, 70 \%, 95 \%$, and twice with a $100 \%$ ethanol solution, in series, respectively. The samples were gradually infiltrated and embedded in Spurr epoxy resin, and sectioned $(1 \mu \mathrm{m})$ using an ultramicrotome (Reichert Supernova; Leica, Vien, Austria) with a glass knife. Anther sections were stained with toluidine blue and examined under an LM (BH-2).

SCANNING ELECTRON MICROSCOPY (SEM). Samples prefixed in the FAA solution were dehydrated for $10 \mathrm{~min}$ in a $50 \%, 70 \%, 95 \%$, and twice with $100 \%$ ethanol solution, in series, respectively, to the critical dry point. The anthers were mounted on SEM stubs, coated with gold-palladium (Polaron SC7620; VG Microtech, Uckfield, England), and examined with a SEM (JSM-5600LV; Jeol, Tokyo).

Statistical AnALYsis. Analyses of variance were performed using Minitab (version 13.20; Minitab Inc., State College, Pa.). Mean separations with Duncan's multiple range test were applied using the MSTAT-C (version 2.1; Michigan State University, East Lansing) at $P \leq 0.05$. Additionally, the coefficient of variation (CV) was calculated for dimensions of the anthers.

\section{Results}

Staminate flower Structure. Significant differences were found in male-sterile and male-fertile chestnut cultivars with respect to their stamen formation. 'Firdola' and 'Karamehmet' had long filaments. The stamens possessed distinct flowering and the exterior of the tepal leaves (perigon) (Fig. 1A). 'Sariaslama' also had stamens longer than tepals but these stamens were much shorter than those of the previous cultivars (Fig. 1B). 'Haciomer' had stamens as long as the perigon (Fig. 1C). 'Osmanoglu' and 'Vakit Kestanesi' had stamens shorter than the perigon and possessed no visible flowering (Fig. $1 \mathrm{D}$ and E).

A flower cluster of the staminate catkins of the cultivars contain approximately seven flowers (Table 1). The mean stamen number of the staminate flower of the cultivars varied from 9.50 to 11.95 , except for the 'Osmanoglu' with only 2.60 stamens per flower.

Stamen structure. 'Firdola', 'Karamehmet', 'Sariaslama', and 'Haciomer' had normal stamens (Fig. 2A-D). Their anthers
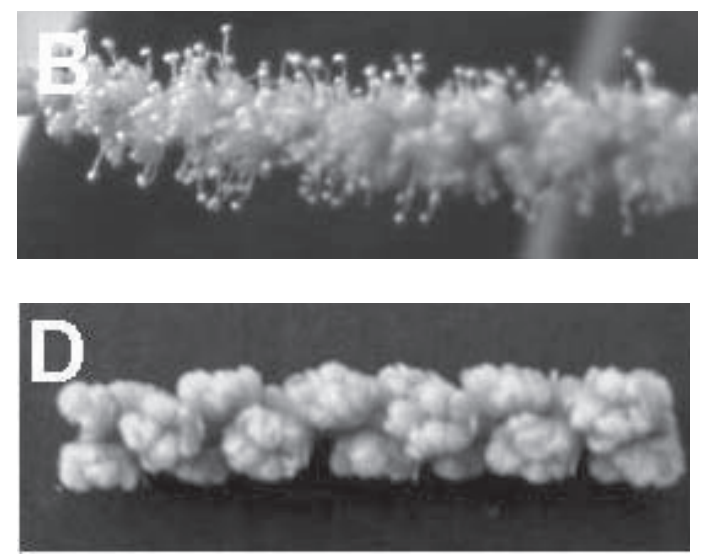

Fig. 1. Appearance of staminate inflorescences in full bloom in male-fertile chestnut cultivars (A) Karamehmet, (B) Sariaslama, (C) Haciomer; and male-sterile chestnut cultivars (D) Osmanoglu and (E) Vakit Kestanesi. 
Table 1. The mean number of flowers per cluster, the mean number of stamens per flower, dimensions, and coefficients of variation of anthers, and the number of pollen grains per anther of male-fertile and male-sterile chestnut cultivars.

\begin{tabular}{|c|c|c|c|c|c|c|c|}
\hline Cultivars & $\begin{array}{c}\text { Flowers } \\
\text { (no./cluster) }\end{array}$ & $\begin{array}{c}\text { Stamens } \\
\text { (no./flower) }\end{array}$ & $\begin{array}{c}\text { Anther width } \\
{[\text { mean } \pm \mathrm{SE}(\mu \mathrm{m})]}\end{array}$ & $\mathrm{CV}^{\mathrm{z}}(\%)$ & $\begin{array}{c}\text { Anther length } \\
{[\text { mean } \pm \mathrm{SE}(\mu \mathrm{m})]}\end{array}$ & $\mathrm{CV}(\%)$ & $\begin{array}{c}\text { Pollen grains } \\
\text { (no./anther) }\end{array}$ \\
\hline Firdolay & 7.77 & 11.80 & $334.6 \pm 43.4 \mathrm{c}^{\mathrm{x}}$ & 12.99 & $464.6 \pm 50.7 \mathrm{a}$ & 10.91 & $5100 \mathrm{a}$ \\
\hline Karamehmety & 6.63 & 11.95 & $348.2 \pm 47.4 \mathrm{c}$ & 13.62 & $431.8 \pm 49.7 \mathrm{bc}$ & 11.53 & $5200 \mathrm{a}$ \\
\hline Sarıaslamay & 7.50 & 11.75 & $320.6 \pm 25.5 c$ & 7.98 & $411.0 \pm 33.4 \mathrm{bc}$ & 8.13 & $4700 \mathrm{a}$ \\
\hline Haciömery & 7.37 & 11.80 & $443.0 \pm 23.9 \mathrm{a}$ & 5.41 & $432.0 \pm 32.6 b$ & 7.54 & $3850 \mathrm{a}$ \\
\hline Osmanoglu ${ }^{\mathrm{w}, \mathrm{v}}$ & 6.93 & 2.60 & $392.3 \pm 41.1 b$ & 10.48 & $406.0 \pm 51.0 \mathrm{c}$ & 12.66 & $250 \mathrm{~b}$ \\
\hline Vakit Kestanesiw & 6.97 & 9.50 & $208.8 \pm 28.0 \mathrm{~d}$ & 13.41 & $164.5 \pm 28.9 \mathrm{~d}$ & 17.20 & $120 \mathrm{~b}$ \\
\hline
\end{tabular}

${ }^{2} \mathrm{CV}=$ coefficient of variation.

yMale-fertile chestnut cultivar.

xMean separation in columns by Duncan's multiple range test at $P \leq 0.05$ lowercase letters.

"Male-sterile chestnut cultivar.

vMeasurement was done on anthers that appeared normal.
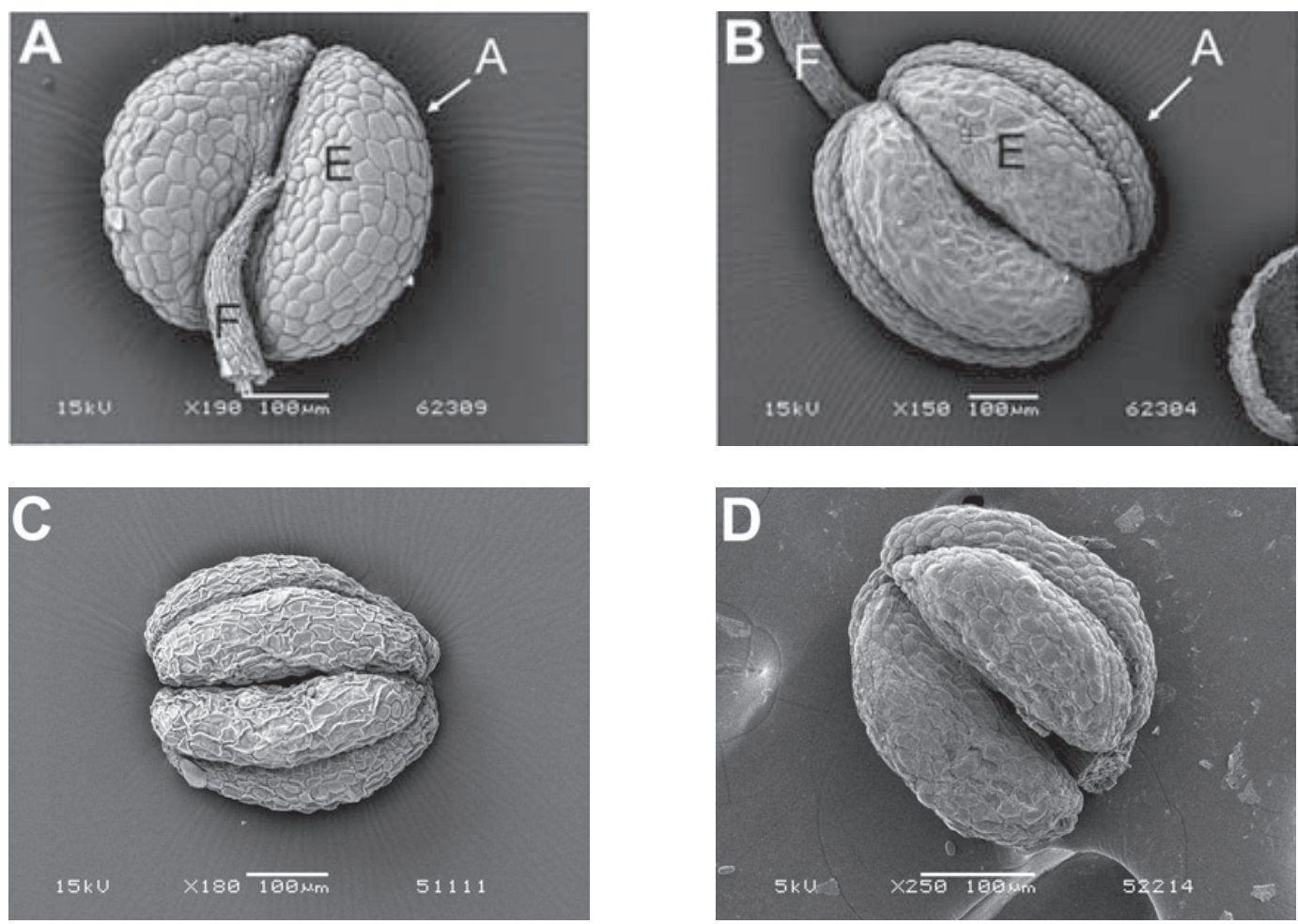

Fig. 2. Scanning electron micrographs of the anthers of male-fertile chestnut cultivars. External anther morphology of (A) 'Firdola', (B) 'Karamehmet', (C) 'Sariaslama', and (D) 'Haciomer;' A = anther, E = epidermis, F = filament.
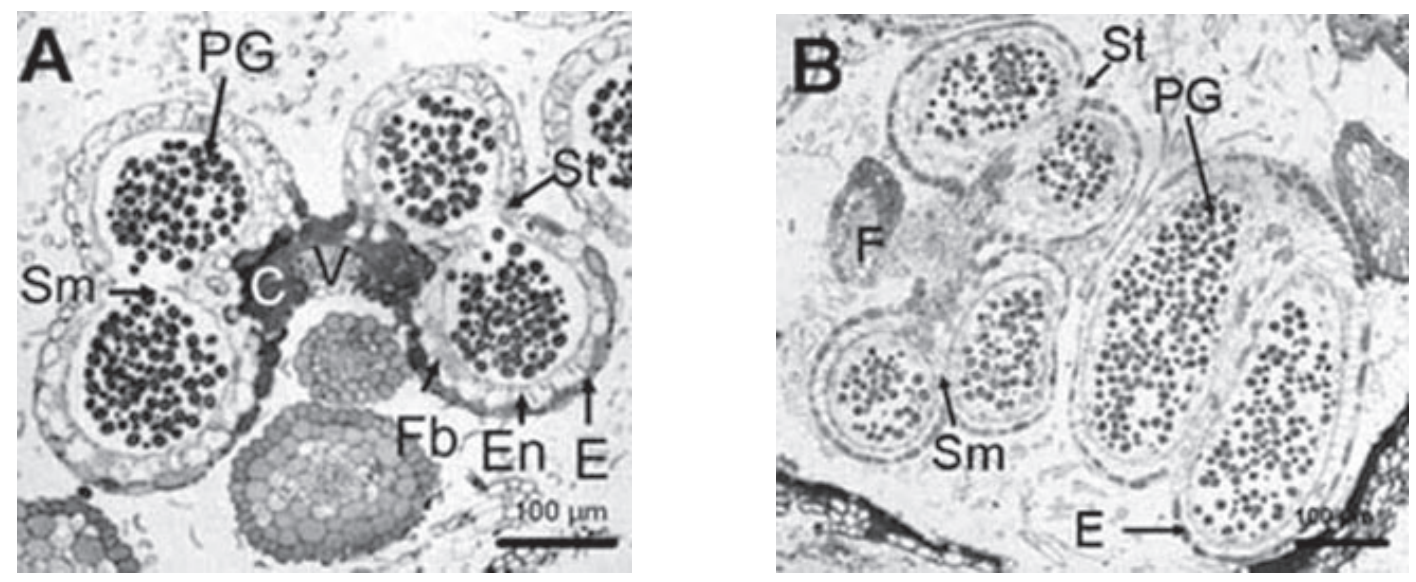

Fig. 3. Transverse section of four locules in (A) 'Firdola' and longitudinal section of (B) 'Sariaslama' chestnut anthers stained with toluidine blue and photographed using light microscopy; $\mathrm{C}=$ connective, $\mathrm{E}=$ epidermis, $\mathrm{En}=$ endothecium, $\mathrm{F}=$ filament, $\mathrm{Fb}=$ fibrous band, $\mathrm{PG}=$ pollen grain, $\mathrm{Sm}=\mathrm{septum}, \mathrm{St}=$ stomium, $\mathrm{V}=$ vascular region. 

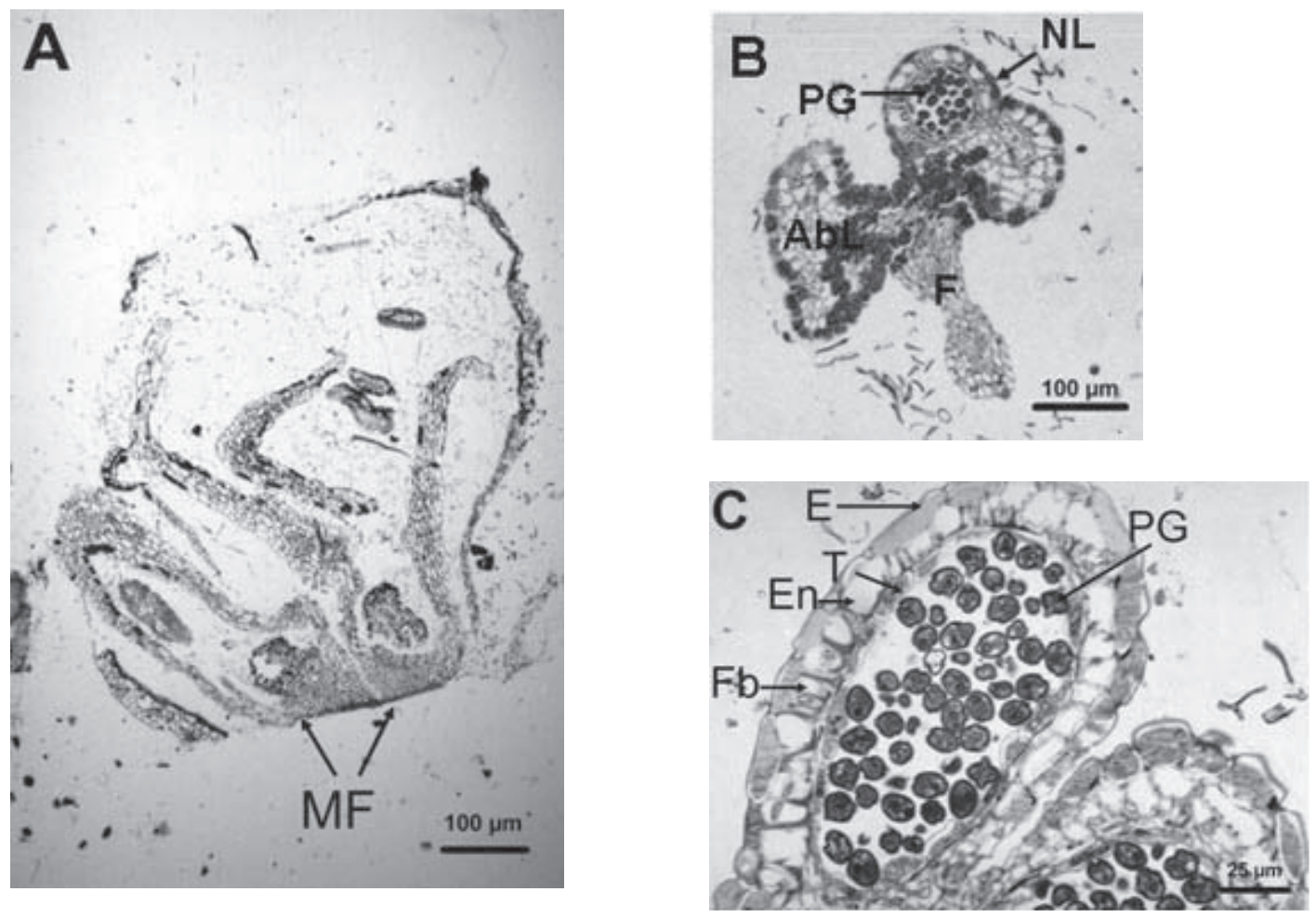

Fig. 4. Transverse section of male-sterile 'Osmanoglu' chestnut flowers (A) without stamen, $(\mathbf{B})$ abnormal lobe without pollen, and $(\mathbf{C})$ normal anther stained with toluidine blue and photographed using light microscopy; $\mathrm{AbL}=$ abnormal lobe, $\mathrm{E}=$ epidermis, $\mathrm{En}=$ endothecium, $\mathrm{F}=$ filament, $\mathrm{Fb}=$ fibrous bunds, $\mathrm{MF}=$ male flower, $\mathrm{NL}=$ normal lobe, $\mathrm{PG}=$ pollen grain, $\mathrm{T}=$ tapetum .

had two lobes while each lobe contained two pollen sacs (Fig. $3 \mathrm{~A}$ and B). Their anthers had the stomium split that releases the mature pollen.

'Osmanoglu' and 'Vakit Kestanesi' had abnormal stamens of different types. Thirty-six percent of the staminate flowers in 'Osmanoglu' were empty without stamens (Fig. 4A). Different types of stamens also existed in the flowers. For instance, some stamens (24.4\%) consisted of only filaments without an anther (Fig. $5 \mathrm{~A})$. Other stamens had abnormal anthers either with a swollen tip (Fig. 5B), or one lobe developed and the other undeveloped (64.5\%) (Figs. 4B and 5C). Nevertheless, the developed lobe had pollen grains (Figs. 4B and 5C). Normally developed anthers were observed together with the abnormal ones in the same flower(Fig. 5D). The ratio of normal anthers was rather low (11.1\%). Normally developed anthers possessed four-lobed structures (Figs. 4C and 5D). These anthers had stomiums; however, pollen release was not observed because the anthers curled into the perigon.

Anthers of 'Vakit Kestanesi' appeared to be normal, but the filaments were very short (Figs. 6A and 7B). The anthers had four lobes (Figs. 6 A and B, 7A). However, in a majority of the anthers the inner tissue did not develop as they did in the normal anthers. This caused no pollen production from the undifferentiated mass of cells (Figs. 6 B and C, 7A). A very
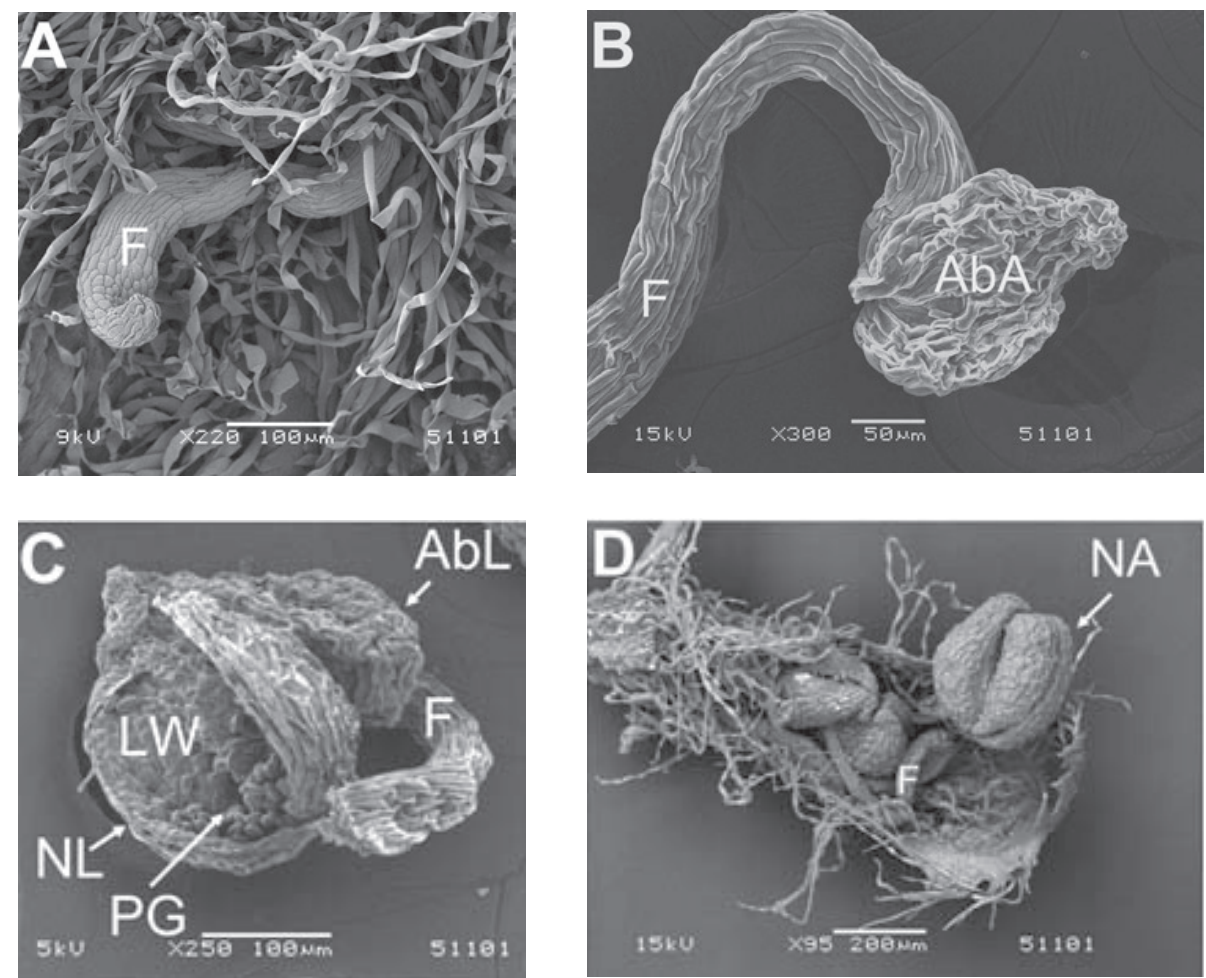

Fig. 5. Scanning electron micrographs of different types of stamens in male sterile 'Osmanoglu' chestnut showing (A) stamen without anther (only filament), (B) stamen with abnormal anther, $(\mathbf{C})$ anther with a normal and abnormal lobe, and (D) normal anther; $\mathrm{AbA}=$ abnormal anther, $\mathrm{AbL}=$ abnormal lobe, $\mathrm{F}=$ filament, $\mathrm{LW}=$ inner locule wall, $\mathrm{NA}=$ normal anther, $\mathrm{NL}=$ normal lobe, $\mathrm{PG}$ $=$ pollen grain. 

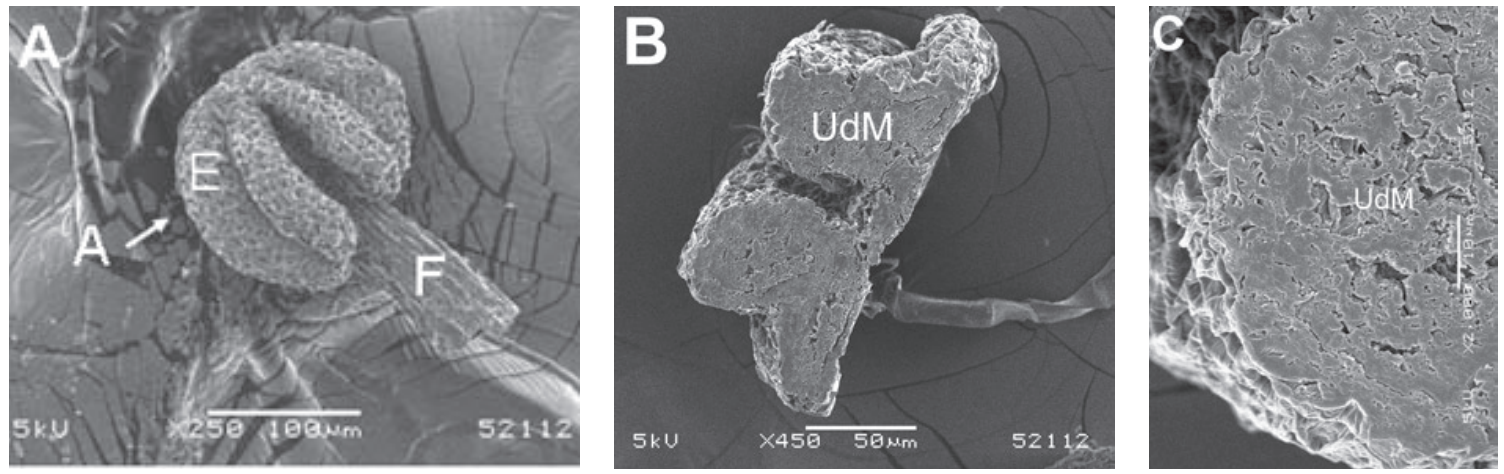

Fig. 6. Scanning electron micrographs of anthers in male-sterile 'Vakit Kestanesi' chestnut. (A) External morphology of the anther. (B) Transverse section of the anther with epidermis covering mass of undifferentiated inner tissues. (C) Undifferentiated mass of cells from locule (bar $=10 \mu \mathrm{m}) ; \mathrm{A}=\mathrm{anther}, \mathrm{E}=\mathrm{epidermis,} \mathrm{F}$ = filament, $\mathrm{UdM}=$ undifferentiated mass of cells.
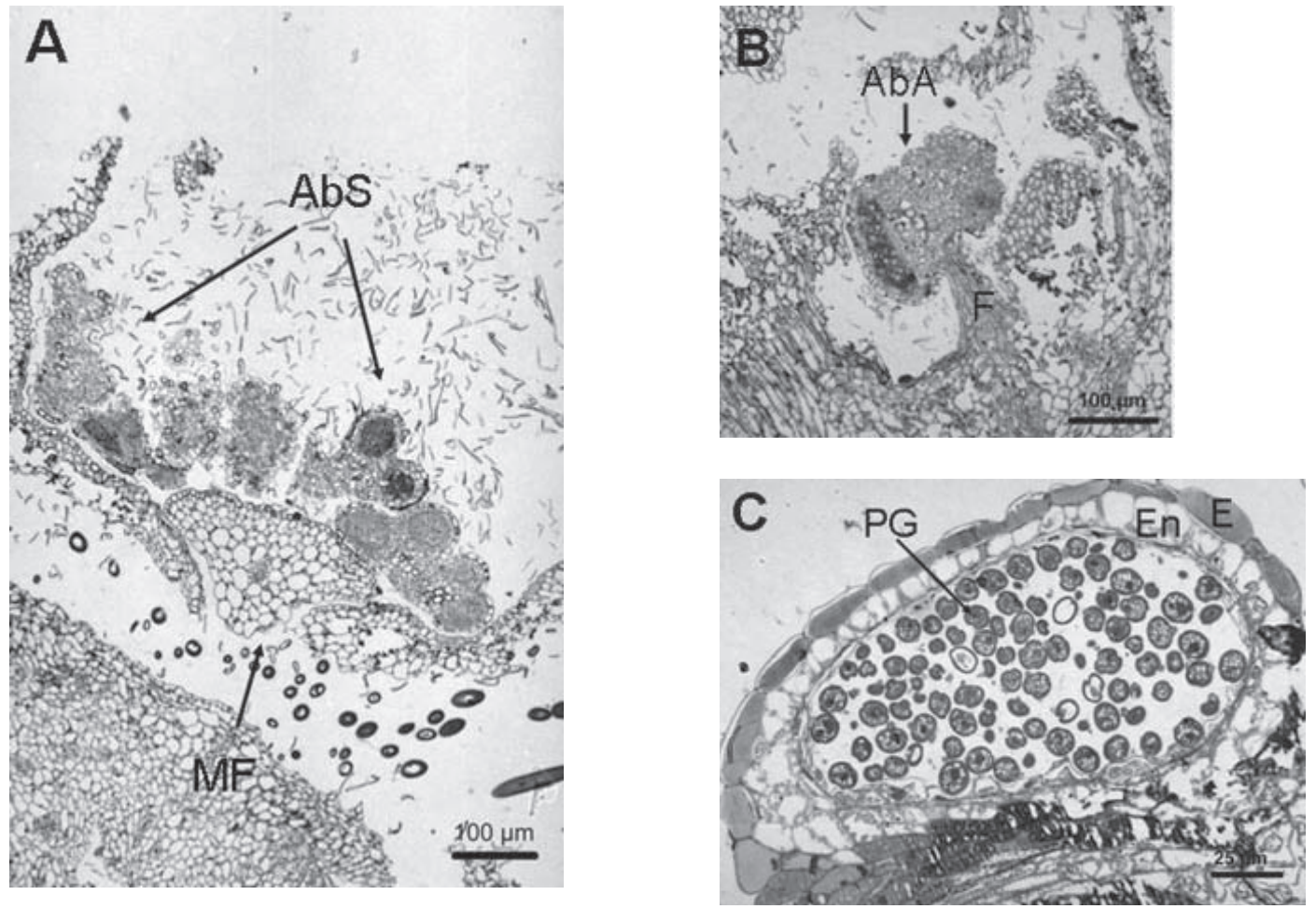

Fig. 7. Transverse sections of male-sterile 'Vakit Kestanesi' chestnut with (A) abnormal stamens in the flower, (B) abnormal stamen, (C) a locule in transverse section of normal anther $(\mathrm{bar}=25 \mu \mathrm{m})$ stained with toluidine blue and photographed using light microscopy; $\mathrm{AbA}=$ abnormal anther, AbS $=$ abnormal stamen, $\mathrm{E}$ = epidermis, $\mathrm{En}=$ endothecium, $\mathrm{F}=$ filament, $\mathrm{MF}=$ male flower, $\mathrm{PG}=$ pollen grain .

low percentage of anthers (2.6\%) produced pollen grains (Fig. 7C), and these anthers had stomiums.

ANTHER SURFACE MORPHOLOGY AND DIMENSIONS. Three different types of surface structure were determined among the cultivars. Male-fertile cultivars had similar surface morphology. However, male-sterile cultivars had a surface morphology that was not only different from the male-fertile cultivars but also from each other. Anther surface structure of 'Firdola', 'Karamehmet', 'Sariaslama', and 'Haciomer' consisted of polygonal epidermal cells (Fig. 8A-D). 'Osmanoglu' also had polygonal surface cells. However, these cells whose surface had thread-like structures were longer and thin (Fig. 8E). 'Vakit Kestanesi' had a completely different surface structure from the previous cultivars. This cultivar had polygonal surface cells that had hollow centers. Its edges were swollen, and it had a reticulate appearance (Fig. 8F).
Anther dimensions were different among the cultivars (Table 1). 'Haciomer' had the widest value and 'Firdola' had the longest. Both values were significantly lower in 'Vakit Kestanesi' compared with the other cultivars (Table 1). Normal anthers of 'Firdola', 'Karamehmet', and 'Osmanoglu' are round, elliptical, and long while those of 'Haciomer' and 'Vakit Kestanesi' are round, elliptical, and wide.

Coefficients of variation of anther dimensions were low (5-8) in 'Sariaslama' and 'Haciomer', medium (10-13) in 'Firdola', 'Karamehmet', and 'Osmanoglu', and high (13-17) in 'Vakit Kestanesi' (Table 1).

Structure of the tissue SURRounding the ANTHER. Malefertile cultivars showed a normal organization of the layer structures consisting of tapetum, endothecium, an outer layer, and an epidermal layer (Fig. 9 A and B). However, in male-sterile 

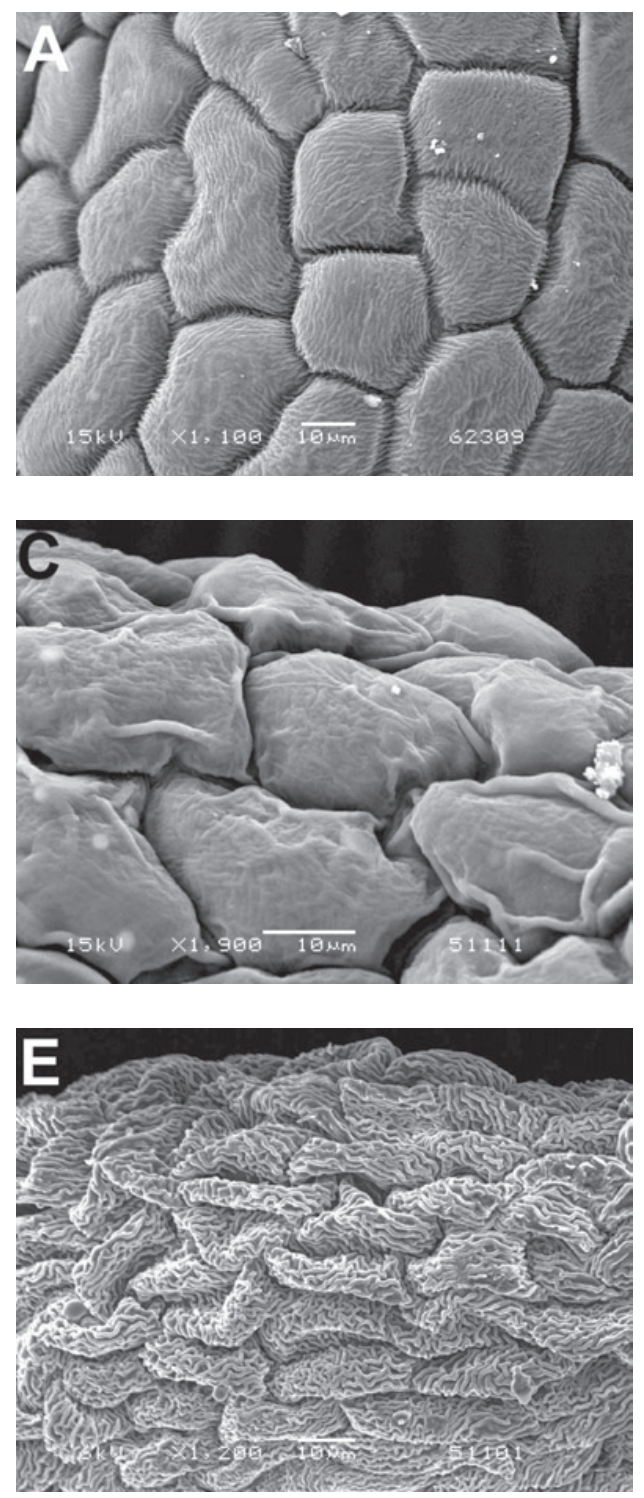
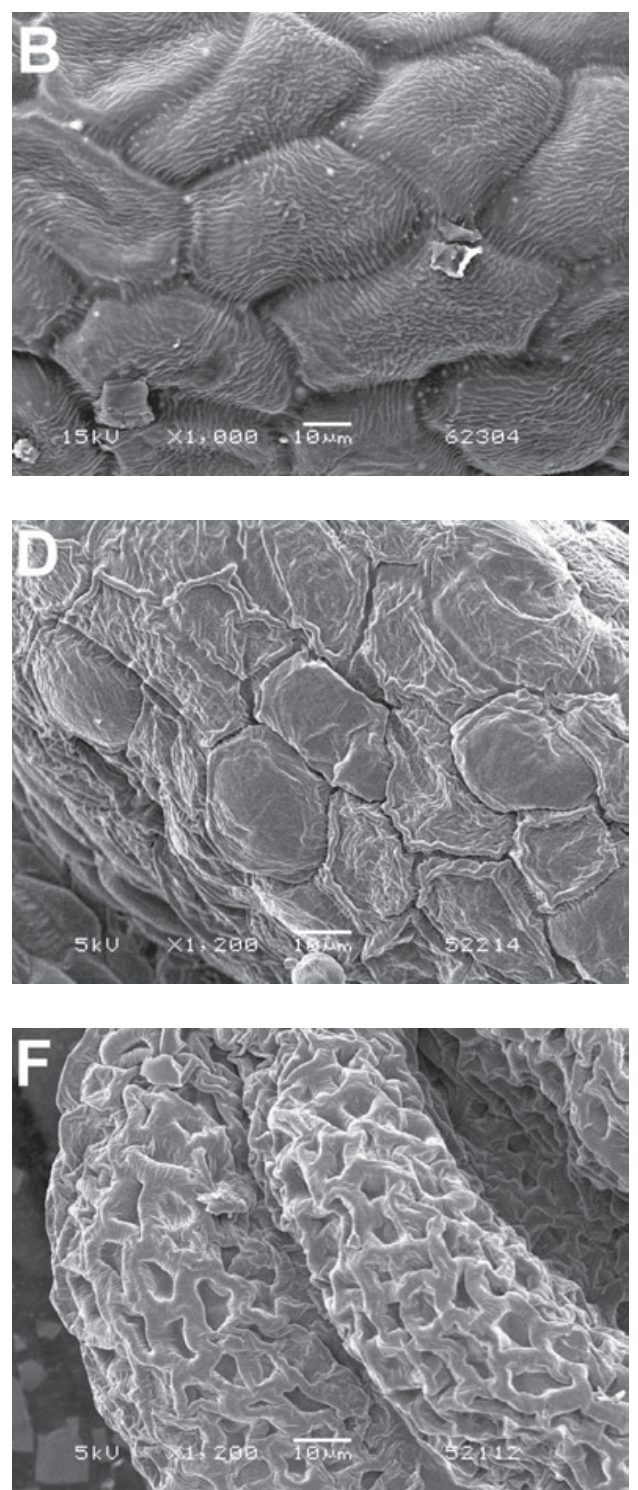

Fig. 8. Scanning electron micrographs of anther surface structures of male-fertile chestnut cultivars (A) Firdola, (B) Karamehmet, (C) Sariaslama, and (D) Haciomer; and male-sterile chestnut cultivars (E) Osmanoglu and (F) Vakit Kestanesi.
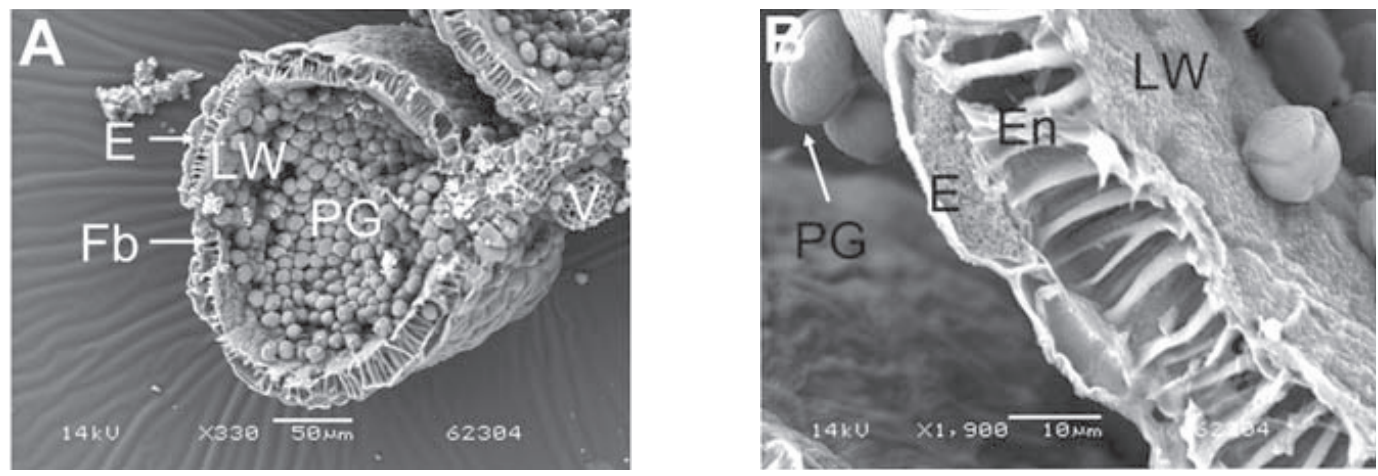

Fig. 9. Scanning electron micrographs of (A) an anther lobe and (B) the anther wall in 'Firdola' chestnut; $\mathrm{E}=$ epidermis, En $=$ endothecium, $\mathrm{Fb}=$ fibrous band, $\mathrm{LW}$ $=$ inner locule wall, $\mathrm{PG}=$ pollen grain, $\mathrm{V}=$ vascular region . 

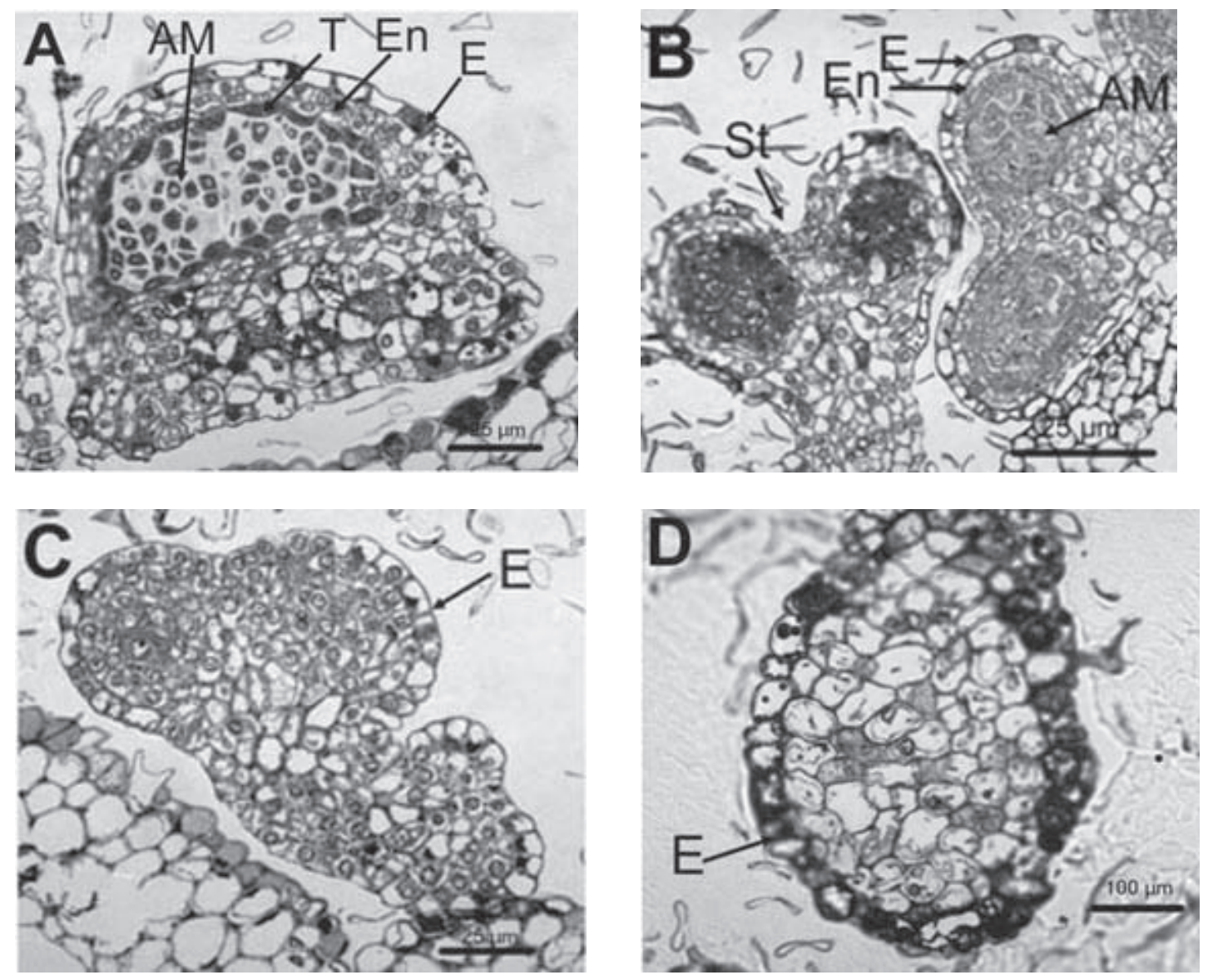

Fig. 10. Transverse sections of anther locules in (A-C) male-sterile 'Vakit Kestanesi' and (D) 'Osmanoglu' chestnut. Transverse sections stained with toluidine blue and photographed using light microscopy. Pollen development is (A) aberrant, (B) two-loculated abnormal anther, (C) anther with epidermis covering undifferentiated inner tissue, and (D) anther lobe with epidermis covering undifferentiated inner tissue; $\mathrm{AM}=$ aberrant material, $\mathrm{E}=\mathrm{epidermis}, \mathrm{En}=\mathrm{endothecium}$, $\mathrm{St}=$ stomium, $\mathrm{T}=$ tapetum

cultivars (e.g., 'Vakit Kestanesi'), three different types of anther wall structure were observed. Some walls had three clear layers similar to those of fertile anthers (Fig. 10A). Some had a twocell layer (Fig. 10B) while the others had only a one-cell layer structure (Fig. 10C). 'Osmanoglu' had only one layer of cells in abnormal anthers (Fig. 10D). Normal anthers of the male-sterile genotypes had a similar structure to the male-fertile genotypes (Figs. 4C and 7C).

Pollen PROduction In THE anTHERs. Significant differences were determined between the male-fertile and male-sterile cultivars with respect to the pollen number in the anthers. The pollen number in an anther varied from 120 to 5200 among the cultivars (Table 1). There was a sharp decrease in numbers of pollen from male-fertile to the male-sterile cultivars. A majority of the anthers produced no pollen in the male-sterile genotypes. The mean numbers were very low in 'Vakit Kestanesi' and 'Osmanoglu', 120 and 250 , respectively.

\section{Discussion}

Studies concerning floral structures of chestnuts have shown that various types of staminate flowers can be seen in the genus Castanea L. (Jaynes, 1963). European researchers have focused on this phenomenon and divided the chestnuts into four major groups with respect to the staminate flower morphology (Breviglieri, 1951; Morettini, 1949; Schad and Solignat, 1952; Solignat, 1958,
1973; Soylu and Ayfer, 1981). Our results supported the presence of four major groups of staminate flower morphology.

Staminate flower clusters had generally six to seven flowers. This is consistent with the findings of previous researchers (Abbe, 1974; Bergamini, 1975; Soylu and Ayfer, 1981). Eight to nine flowers rarely can be found in a cluster. Brett (1964) reported up to 15 flowers per cluster in C. sativa. One staminate flower had 9.50 to 11.95 stamens in most of the cultivars studied, except 'Osmanoglu', which had 2.60 stamens per flower. Abbe (1974) noted that the number of stamens per flower varied from 8 to 12 . Similarly, Soylu and Ayfer (1981) found that the number of stamens per flower ranged between 8.4 and 11.5, and was 2.9 in 'Osmanoglu'. Our results are in agreement with the previous studies.

Anther structures of the cultivars have shown significant differences especially between the two male-sterile cultivars. In male-sterile 'Vakit Kestanesi', the anthers were small, shrunken, and pale in color. The inner tissue of the anthers did not differentiate and often consisted of a mass of cells. This structural feature has been noticed for the first time in chestnuts, in this study. In addition, only a few anthers produced pollen grains as previously reported by Soylu and Ayfer (1981). Abortive small anthers that produce no pollen were reported in some other plant species (Duvick, 1965; Kaul, 1988). Sanders et al. (1999) determined some mutants without pollen grains in Arabidopsis thaliana (L.) Heynh. A lack of pollen grains in the plants was attributed to the meiotic aberrations during meiosis or abnormalities of 
the locule cells. Similarly, in some male-sterile apricot (Prunus armeniaca L.) cultivars, shrunken anthers were observed. These anthers produced few or no pollen (Medeira and Guedes cited in Lillecrapp et al., 1999).

A different sterility phenomenon was observed in 'Osmanoglu'. This cultivar had shown four different kinds of status in this respect. In the first class, the staminate flowers had no stamens. In the second class, the stamens had only filaments without an anther. In the third class, the stamens had only abortive anthers. Some anthers had both normal and abnormal locules. Finally in the fourth class, stamens had normal anthers.

In this respect, these results are partially different from previous reports (Bencat, 1964; Breviglieri, 1951; Graves, 1962; Morettini, 1949; Schad and Solignat, 1952) since there was no pure genotype without a stamen among the cultivars examined. In some other plant species, for example in A. thaliana, some male sterile ( $m s$ ) mutants do not form stamens (Coen and Meyerowitz, 1991; Hill and Lord, 1989). Some mutants have filaments while anther locules do not develop normally, or convert to a leafy structure (Chudhury et al., 1992). Flowers without anthers have been observed in maize (Zea mays L.) recessive (at) mutants (Kaul, 1988; Weijer, 1952). Malformed anthers have evolved in a dominant mutant $m s 4$ in cotton (Gossypium L.) (Allison and Fisher cited in Chaudhury, 1993). Omura and Akihama (1980) reported genotypes without anthers in $C$. sativa and related hybrids. All of these phenotypes have been observed separately in various plant species, but 'Osmanoglu' is the only chestnut genotype to show the presence of all the modifications based on our findings.

Surface structures of the anthers were different among the cultivars. Although the male-fertile cultivars had structures similar to one another, the male-sterile ones had different surface morphology. Hence, further research is needed to determine if this characteristic is wholly related to male sterility in chestnuts. The surface morphology of the anthers can be used as a species identification character in some pear (Pyrus L.) species (Westwood and Challice, 1978).

The surrounding tissues of the anthers consisted of a surface epidermis, endothecium, middle layers, and tapetum in malefertile cultivars as explained by Esau (1977) for Angiospermae. In this regard, male-sterile cultivars showed no differentiation in some cases.

Pollen production levels can be used as an indicator for male sterility. In this study, male-sterile cultivars produced very few pollen $(2.8 \%$ to $4.8 \%$ of the fertile ones). Other researchers also noticed that, as male-sterile genotypes produced a low quantity of pollen (Breviglieri, 1955; Schad and Solignat, 1952; Solignat, 1958; Soylu and Ayfer, 1981).

In conclusion, stamen length, the dimensions of the anther and the structure of the anthers' inner part and of its surrounding tissue, and the pollen production capability of the anthers were determined as the main correlative characteristics for male-sterility.

\section{Literature Cited}

Abbe, A.C. 1974. Flowers and inflorescences of the "Amentiferae." Bot. Rev. 40:159-261.

Ayfer, M., A. Soylu, G. Celebioglu, S. Mermer, and H. Saglam. 1986. Selection of chestnut cultivars (Castanea sativa Mill.) in Marmara region (in Turkish with English abstract). Bahçe 15:71-81.

Bencat, F. 1964. Morphological and physiological dioecism in Castanea sativa under the condition of Slovakia. Biologia 19:912-917 (Hort. Abstr. 36:6317).
Bergamini,A. 1975. Observations on the floral morphology of some chestnut varieties. Rivista della Ortoflorofrutticoltura Italiana 59:103-108 (Plant Breeding Abstr. 46:5724).

Bolvansky, M. and L. Mendel. 1999. Inheritance of some fruit and flower characteristics in full-sib progenies of chestnut. Acta Hort. 494:339-344.

Brett, D.W. 1964. The inflorescence of Fagus and Castanea, and the evolution of the cupules of the Fagaceae. New Phytol. 63:96-118.

Breviglieri, N. 1951. Ricerche sulla biologia fiorale e di fruttificazione della Castanea sativa e Castanea crenata nel torritorio di Vallombrosa. Centro di Studio Sul Castagno 1:15-49.

Breviglieri, N. 1955. Ricerche sulla disseminazione e sulla germinazione del polline nel castagno. Centro di Studio Sul Castagno 2:5-25.

Chaudhury, A.M. 1993. Nuclear genes controlling male fertility. Plant Cell 5:1277-1283.

Chaudhury, A.M., S. Craig, L. Farrell, K. Bloemer, and E.S. Dennis. 1992. Genetic control of male-sterility in higher plants. Austral. J. Plant Physiol. 19:419-425.

Coen, E.S. and E.M. Meyerowitz. 1991. The war of the whorls: Genetic interactions controlling flower development. Nature 353:31-37.

Duvick, D.N. 1965. Cytoplasmic pollen sterility in corn. Adv. Genet. 13:1-56.

Esau, K. 1977. Anatomy of seed plants. Wiley, New York.

Graves, A.H. 1962. Some outstanding new chestnut hybrids II. Bul. Torrey Bot. Club 89:161-172.

Hill, J.P. and E.M. Lord. 1989. Floral development in Arabidopsis thaliana comparison of the wild-type and the homeotic pistillata mutant. Can. J. Bot. 67:2922-2936.

Jaynes, R.A. 1963. Male sterility in Castanea. Proc. XI. Intl. Congr. of Genet. The Hague, The Netherlands, p. 203 (Abstr.).

Kaul, M.L.H. 1988. Male sterility in higher plants. Springer-Verlang. Berlin.

Lillecrapp, A.M., M.A. Wallwork, and M. Sedgley. 1999. Female and male sterility cause low fruit set in a clone of the 'Trevatt' variety of apricot (Prunus armeniaca). Scientia Hort. 82:255-263.

Morettini, A. 1949. Floral biology in the chestnut. L' Italia Agricola 86:721-731 (Hort. Abstr. 20:1410).

Omura, M. and T. Akihama. 1980. Male sterility in chestnuts: A tentative plan for the seed propagation of fruit trees. Gamma Field Symp. 19:77-89.

Sanders, P.M., A.Q. Bui, K. Weterings, K.N. McIntire, Y.-C. Hsu, P.Y. Lee, M.T. Truong, T.P. Beals, and R.B. Goldberg. 1999. Anther developmental defects in Arabidopsis thaliana male-sterile mutants. Sexual Plant Reproduction 11:297-322.

Sass, J.E. 1958. Botanical microtechnique. Iowa State University Press, Ames.

Schad, C. and G. Solignat. 1952. Biologie florale et méthodes d'amélioration du chataignier. Acadèmie d'Agriculture de France, Extrait du proces-verbal de la Séance du 14 Mai 1-3.

Solignat, G. 1958. Observations sur la biologie du chataignier. Annales L' Amélioration Des Plantes 8:31-58.

Solignat, G. 1973. Un renouveau de la chataigneraie fruitière. Institut National de la Recherche Agronomique, Centre de Recherches Agronomiques de Bordeaux, Bulletin d'Information 280:425-450.

Soylu, A. 1992. Heredity of male sterility in some chestnut cultivars (Castanea sativa Mill.). Acta Hort. 317:181-185.

Soylu, A. and M. Ayfer. 1981. Studies on floral biology and fruit setting of some important chestnut cultivars (Castanea sativa Mill.) grown in Marmara region (in Turkish with English abstract). Bahçe 10:45-65.

Szabó, Z., B. Timon, and E. Felhósné Váczi. 1996. Morphological characteristics of flowers of several peach varieties. Acta Hort. 374:127 (Abstr.).

Weijer, J. 1952. A catalogue of genetic maize types together with a maize bibliography. Bibliographia Genetica 14:189-425.

Westwood, M.N. and J.S. Challice. 1978. Morphology and surface topography of pollen and anthers of Pyrus species. J. Amer. Soc. Hort. Sci. 103:28-37. 